\title{
CHEMICAL COMPOSITION AND EVALUATION OF PROTEIN QUALITY BY AMINO ACID SCORE METHOD OF EDIBLE BROWN MARINE ALGAE ARAME (EISENIA BICYCLIS) AND HIJIKI (HIJIKIA FUSIFORME)
}

\author{
N. KOLB ${ }^{\mathrm{a}, \mathrm{c}}$, L. VALLORANI $^{\mathrm{b}}$ and V. STOCCHI ${ }^{\mathrm{b}}$ \\ ${ }^{a}$ Faculty of Food Technology and Biotechnology, University of Zagreb, \\ Pierottijeva 6, 10000 Zagreb. Croatia \\ b Instituto di Chimica Biologica "Giorgio Fornaini" Università degli studi di Urbino, \\ Via Saffi, 2, 61029 Urbino. Italia
}

(Received: 6 April 1998; accepted: 18 January 1999)

Crude proteins and their amino acid composition, fats, carbohydrates, cellulose, ashes, nucleic acids and minerals were determined in two edible and commercially available brown marine algae (Phaeophyceae), Arame (Eisenia bicyclis) and Hijiki (Hijikia fusiforme). The essential amino acid ratios for five key essential amino acids as well as the amino acid score based on the first limiting amino acid, Lys-Met-Cys score, Lys-Met-Cys-Trp score and Lys-Met-CysTrp-Thr score were calculated. The results have shown:

- rather high contents of proteins, containing all essential amino acids

- high amino acid ratios which are nearly as high as the value suggested by FAO/WHO/UNU pattern or higher

- the first limiting amino acid in both analysed algae is tryptophane

- very low contents of fats and nucleic acids

- high contents of cellulose and other carbohydrates

- large quantities of minerals and very low amounts of heavy metals.

Keywoods: Arame, Hijiki, chemical composition, protein quality, amino acid scoring

Eisenia bicyclis and Hijikia fusiforme, commercially named Arame and Hijiki, respectively, are marine macroalgae classified as brown algae or Phaeophyceae. In Japan and the Far East these marine algae are regulary utilised in human alimentation since ancient times, while in European countries their use is only occasional (LAHAYE, 1991). With the spreading of the so called alternative diet like macrobiotic way of nutrition, the edible marine algae although in small quantities are consumed daily.

\footnotetext{
${ }^{\mathrm{c}}$ Author to whom correspondence should be addressed.
} 
Generally the marine algae are a good source of carbohydrates (FLEURY \& LAHAYE, 1991), proteins, vitamines and minerals (FUJIWARA-ARASAKI et al., 1984). The algal carbohydrates: carrageenan, agar, alginate, cellulose, laminarans, fucans are undigestible by man and therefore considered dietary fibres (FLEURY \& LAHAYE, 1991). Furtheremore, due to their polysaccharidic structure, brown algae are particularly suitable for binding metallic ions, so lead and cadmium can be easily removed from dilute solutions by algal biomass (VOLESKY \& HOLAN, 1995).

The algal proteins contain all essential amino acids, and the vitamine B-complex, $\beta$-carotene and vitamin $\mathrm{C}$ are determined.

The contents of iodine, calcium and iron are claimed to be greater than in vegetables and fruits used in traditional western diet (FUJIWARA-ARASAKI, 1984).

Marine algae are the source of safe and effective natural antioxidants (CAHYANA et al., 1992). As for some medical applications, the marine algae can develop antibiotic activity against multi-antibiotic resistant bacteria (MAHASNEH et al., 1995), and play a protective role against carcinogens (OKAI et. al., 1997).

The objective of this work was to evaluate Arame and Hijiki as natural and useful food supplements in our western staple diet.

\section{Materials and methods}

Arame (Eisenia bicyclis) and Hijiki (Hijikia fusiformis) imported from Japan, were bought dry in a local health store. The samples were pulverised and the chemical composition (crude proteins $(\mathrm{N} \times 6.5)$, fat, cellulose, ash and iodine) was determined according to A.O.A.C. method (1990). Minerals were determined by atomic absorption spectrophotometer Perkin Elmer 3030 B according to A.O.A.C. (1990). Phosphorous was determined by spectrophotometric method according to A.O.A.C. method (1990). Nucleic acids were determined by spectrophotometric method (RUT, 1973).

\subsection{Amino acids analyses}

1.1.1. Chemicals. DABS-Cl was purchased from Fluka (Buchs, Switzerland). A standard calibration mixture of amino acids of the highest grade and $6 \mathrm{moll}^{-1}$ hydrochloric acid (constant boiling, sequanal grade) were obtained from Pierce (Pierce Chemical Co., Rockford, IL). Acetonitrile, methanol, acetone and ethanol of HPLC grade and $\mathrm{NaOH}$ were obtained from Carlo Erba (Farmitalia, Italy). Analytical reagent grade potassium dihydrogen phosphate was purchased from Merck (Darmstadt, Germany). Triple-distilled water was prepared in the laboratory and used for the preparation of buffers. The buffer A used for the HPLC analyses was filtered through a $0.22 \mu \mathrm{m}$ Millipore filter (Millipore Corp., Milford, MA). 
1.1.2. Preparation of DABS-derivatives. DABS-Cl solution $\left(4 \mathrm{nmol} \mu \mathrm{l}^{-1}\right.$ acetonitrile) was prepared according to the method of CHANG and co-workers (1983) with slight modifications (STOCCHI et al., 1985; STOCCHI et al., 1989). Dried samples were resuspended in $50 \mu \mathrm{l}$ of $0.2 \mathrm{~mol} \mathrm{l}^{-1}$ sodium hydrogen cabonate, $\mathrm{pH} 9.0$ and treated with $100 \mu \mathrm{l}$ of DABS- $\mathrm{Cl}$ solution $\left(4 \mathrm{nmol} \mu \mathrm{l}^{-1}\right.$ acetonitrile). The mixture was left at $70{ }^{\circ} \mathrm{C}$ for $10 \mathrm{~min}$ and then dried under vacuum. The residue was redissolved in a proper volume of $70 \%(\mathrm{v} / \mathrm{v})$ ethanol, and $20 \mu \mathrm{l}$ of this volume was used for amino acids determination.

1.1.3. Liquid phase hydrolysis with $\mathrm{HCl}\left(\mathrm{c}=6 \mathrm{~mol} \mathrm{l}^{-1}\right)$. The pyrex hydrolysis tubes $(10 \mathrm{~cm} \times 7 \mathrm{~mm}$ i.d.) for high sensitivity amino acids analysis were freed from amino acid contaminations by heating at $600{ }^{\circ} \mathrm{C}$ overnight. Hydrolysis was carried out as follows: $10 \mathrm{mg}$ of each dried and powdered sample was placed into a pyrex tube, treated with $1 \mathrm{ml}$ of $6 \mathrm{~mol} \mathrm{l}^{-1}$ hydrochloric acid (constant boiling, sequanal grade), sealed under vacuum and left at $110^{\circ} \mathrm{C}$ for $22 \mathrm{~h}$.

Twenty $\mu \mathrm{l}$ of the hydrolysed sample were pipetted into a test tube, dried under vacuum and derivatized (STOCCHI et al., 1989).

1.1.4. Alkaline hydrolysis with $\mathrm{NaOH}$. Alkaline hydrolysis, using $4.2 \mathrm{~mol} \mathrm{l}^{-1}$ $\mathrm{NaOH}$, was performed to check the recovery of tryptophane in protein samples with high sugar concentration. The hydrolysis was performed according to the method of HUGLI and MOORE (1972).

1.1.5. HPLC analysis. A Gold liquid chromatographic system from Beckman (Beckman, Berkeley, CA) was used for amino acid analyses. The HPLC apparatus consisted of two Model 126 pumps, a PC-8300 solvent programmer, a Model 210 sample injection valve, a $20 \mu \mathrm{l}$ injection loop, and a Model 166 variable wavelength UV-visible range detector, equipped with a $12 \mu \mathrm{l}$ flow cell. Integration of peak areas was obtained by means of the Gold software. Separation of DABS-amino acids was performed using a $3 \mu \mathrm{m}$ Supelcosil LC-18 T column $(15 \mathrm{~cm} \times 4.6 \mathrm{~mm}$ i.d. $)$ protected with a $5 \mu \mathrm{m}$ Supelcosil LC-18 T guard column $(2 \mathrm{~cm} \times 4.6 \mathrm{~mm}$ i.d.) obtained from Supelco (Supelco, Bellefonte, PA). Solvent A was $25 \mathrm{mM}$ potassium dihydrogen phosphate buffer, $\mathrm{pH} 7.05$ and solvent B was acetonitrile and methanol (70:30). The gradient was 1 min at $20 \%$ of solvent B, 5 min up to $25 \%$ of solvent B, 14 min at $25 \%$ of solvent B, 1 min up to $32 \%$ of solvent B, 6 min at $32 \%$ of solvent B, 7 min up to $40 \%$ of solvent B, 9 min up to $60 \%$ of solvent B, 1 min up to $75 \%$ of solvent B, 5 min at $75 \%$ of solvent B.

The gradient was then returned to $20 \%$ of solvent $\mathrm{B}$. The flow rate was $1.5 \mathrm{ml} \mathrm{min}-1$ and detection was performed at $436 \mathrm{~nm}$. 


\section{Results and discussion}

Results are shown in Tables 1-5.

The protein contents in analysed algae are $11.1 \mathrm{~g} / 100 \mathrm{~g} \mathrm{~d} . \mathrm{w}$. for Arame and $7.6 \mathrm{~g} / 100 \mathrm{~g} \mathrm{~d} . \mathrm{w}$. for Hijiki (Table 1). The amino acid analysis revealed the presence of all amino acids including all essential amino acids (Table 2). The amount of amino acids in Arame and Hijiki was found to be $9.2 \%$ of dry weight and $6.7 \%$ of dry weight, respectively. It is interesting that in both analysed algae valine is present in the highest amount i.e. $14,0 \%$ of total amino acid content, followed by glutamic acid with $13.0 \%$ in Arame and $11.0 \%$ in Hijiki (Table 2). The presence of essential amino acids is $49.3 \%$ in Arame and $45.2 \%$ in Hijiki of the total amino acid content. Tryptophane, methionine, cystine, lysine and threonine are five key essential amino acids which are likely to be deficient in mixed human diet (SARWAR \& MC DONOUGH, 1990). In both analysed algae tryptophane was found in the lowest amount (Tables 2,3) and represents the first limiting amino acid with amino acid scores of 27 for Arame and 18 for Hijiki (Table 4). In Hijiki cystine was not determined, but the presence of a fairly high content of methionine with an amino acid ratio of 21 is about as high as the contents of sulfur containing amino acids (methionine + cystine) in FAO/WHO/UNU reference protein (FAO/WHO/UNU, 1985) (Table 3). In Arame and Hijiki the amino acid ratio of lysine is about $20 \%$ lower compared with the reference protein, while threonine in both analysed algae exceeds the recommended value (Table 3). In macrobiotic diet Arame and Hijiki are consumed with rice (LEDVINKA, 1986). As the first limiting amino acid in rice is lysine followed by threonine (HOSENEY, 1994), the amino acid content of Arame and Hijiki could be considered supplementary. Rather high values of amino acid scores Lys-Met-Cys, Lys-Met-Cys-Trp and Lys-Met-Cys-Trp-Thr (Table 4) would indicate a good protein quality. However, these data should be corrected for the protein digestibility in vivo (SARWAR et al., 1989).

The fat content (Table 1$)$ in analysed algae are very low $(0.90 \mathrm{~g} / 100 \mathrm{~g}$ d.w. in Arame and $0.70 \mathrm{~g} / 100 \mathrm{~g} \mathrm{~d} . \mathrm{w}$. in Hijiki). According to the literature the algae are richer in unsaturated fatty acids than the land plants. In Phaeophyceae the unsaturated fatty acids are mainly oleic and arachidonic acids (HARWOOD et al., 1988). 
Table 1

Chemical composition of marine algae Arame (Eisenia bicyclis) and Hijiki (Hijikia fusiforme) in $\mathrm{g} / 100 \mathrm{~g} \mathrm{d.w}$.

\begin{tabular}{|c|c|c|c|c|}
\hline \multirow{2}{*}{$\begin{array}{l}\text { Chemical } \\
\text { composition }\end{array}$} & \multicolumn{2}{|c|}{ Arame } & \multicolumn{2}{|c|}{ Hijiki } \\
\hline & $\overline{\mathrm{x}}$ & $\pm \mathrm{s}$ & $\overline{\mathrm{x}}$ & $\pm s$ \\
\hline Proteins & 11.10 & 0.75 & 7.50 & 0.20 \\
\hline Fats & 0.90 & 0.05 & 0.70 & 0.02 \\
\hline Cellulose & 21.50 & 1.20 & 25.50 & 1.40 \\
\hline Ash & 12.00 & 0.80 & 17.10 & 0.90 \\
\hline Carbohydrates & 54.50 & 3.60 & 49.20 & 2.50 \\
\hline Nucleic acids & 0.61 & 0.08 & 0.54 & 0.07 \\
\hline
\end{tabular}

$\overline{\mathrm{x}}$ : means of 3 determinations

\pm s: standard deviation of 3 determinations

Table 2

Amino-acid composition of marine algae Arame (Eisenia bicyclis) and Hijiki (Hijikia fusiforme) in $\mathrm{mg} / \mathrm{gd}$. w.

\begin{tabular}{|c|c|c|c|c|}
\hline \multirow{2}{*}{$\begin{array}{l}\text { Amino } \\
\text { acid }\end{array}$} & \multicolumn{2}{|c|}{ Arame } & \multicolumn{2}{|c|}{ Hijiki } \\
\hline & $\overline{\mathrm{x}}$ & $\pm s$ & $\overline{\mathrm{x}}$ & $\pm s$ \\
\hline Aspartic acid & 7.18 & 0.36 & 6.86 & 0.34 \\
\hline Glutamic acid & 11.95 & 0.52 & 7.48 & 0.30 \\
\hline Serine & 3.51 & 0.25 & 2.63 & 0.26 \\
\hline -Threonine & 6.24 & 0.59 & 3.34 & 0.31 \\
\hline Glycine & 5.26 & 0.25 & 4.20 & 0.20 \\
\hline Alanine & 8.88 & 0.42 & 4.96 & 0.23 \\
\hline Arginine & 2.23 & 0.15 & 1.75 & 0.08 \\
\hline Proline & 3.37 & 0.34 & 2.90 & 0.28 \\
\hline -Valine & 12.86 & 1.15 & 9.47 & 0.85 \\
\hline -Methionine & 1.44 & 0.13 & 1.54 & 0.14 \\
\hline -Isoleucine & 4.35 & 0.37 & 4.48 & 0.40 \\
\hline -Leucine & 6.99 & 0.34 & 5.99 & 0.26 \\
\hline •Phenylalanine & 4.40 & 0.20 & 3.95 & 0.19 \\
\hline$\bullet$ Lysine & 5.02 & 0.25 & 3.61 & 0.18 \\
\hline -Histidine & 3.57 & 0.18 & 1.92 & 0.09 \\
\hline Tyrosine & 2.33 & 0.12 & 1.99 & 0.09 \\
\hline Cystine & 1.84 & 0.07 & N.D. & N.D. \\
\hline -Tryptophane & 0.35 & 0.028 & 0.17 & 0.015 \\
\hline Total & 91.76 & 5.718 & 67.24 & 4.215 \\
\hline
\end{tabular}

-: Essential amino-acids

$\overline{\mathrm{x}}$ : means of 3 determinations

ts: standard deviation of 3 determinations 
Table 3

The essential amino-acid ratios of Arame (Eisenia bicyclis) and Hijiki (Hijikia fusiforme) compared with $\mathrm{FAO} / \mathrm{WHO} / \mathrm{UNU}$ suggested pattern of amino acid requirements in $\mathrm{mg} / \mathrm{g}$ of protein

\begin{tabular}{lrrr}
\hline $\begin{array}{c}\text { Amino } \\
\text { acid }\end{array}$ & Arame & Hijiki & $\begin{array}{c}\text { FAO/WHO/UNU (1985) } \\
\text { reference protein }\end{array}$ \\
\hline HIS & 32 & 25 & 19 \\
ILE & 39 & 60 & 28 \\
LEU & 63 & 80 & 66 \\
LYS & 45 & 48 & 58 \\
MET+CYS & 29 & 21 & 25 \\
PHE+TYR & 61 & 80 & 63 \\
THR & 56 & 45 & 34 \\
TRP & 3 & 2 & 31 \\
VAL & 116 & 487 & 339 \\
Total & 444 & 21 & \\
\hline MET & 13 & N.D. & \\
CYS & 16 & 27 & \\
TYR & 21 & 53 & \\
PHE & 40 & & \\
\hline
\end{tabular}

The amount of carbohydrates is high: $54.5 \mathrm{~g} / 100 \mathrm{~g} \mathrm{d.w}$. for Arame and $49.8 \mathrm{~g} / 100 \mathrm{~g}$ d.w. for Hijiki (Table 1). In brown algae carbohydrates represent the dietary fibres and consist of laminarans, alginates, fucans (LAHAYE, 1991). As the consumption of low-fibre diets is considered a common etiological factor in "civilisation" diseases like digestive problems, metabolic and cardiovascular diseases (TROWELL, 1976), the consumption of algae with other food rich in dietary fibres is obviously an important factor in self-protection of health and improvement of life. Furthermore, in Phaeophyceae the major polysaccharidic component is alginate which is known to have a particular affinity for binding bivalent heavy metals, and form slightly soluble salts, which are excreted by faeces (CONCON, 1988).

The contents of nucleic acids (Table 1) are low. If consumed by man the nucleic acids are metabolised to uric acid, which although mainly excreted by kidney can enter blood circulation. Too high amounts of uric acid in blood circulation could increase the risk to some diseases like gout, arthritis and kidney disorders (LEHNINGER, 1982), so the daily intake from unconventional sources like marine algae should not exceed $2.0 \mathrm{~g}$ of nucleic acids in addition to the usual diet (EDOZIEN, et al., 1970). It means that the intake of about $300 \mathrm{~g}$ d.w. of Arame and $440 \mathrm{~g}$ d.w. of Hijiki should be permitted. 
Table 4

Amino acid scores (\%) for Arame (Eisenia bicyclis) and Hijiki (Hijikia fusiforme)

\begin{tabular}{ccccc}
\hline Algae & $\begin{array}{c}\text { Amino acid } \\
\text { score }\end{array}$ & $\begin{array}{c}\text { Lys-Met- } \\
\text { Cys score }\end{array}$ & $\begin{array}{c}\text { Lys-Met-Cys } \\
\text { Trp score }\end{array}$ & $\begin{array}{c}\text { Lys-Met-Cys } \\
\text { Trp-Thr score }\end{array}$ \\
\hline Arame & 27 & 96 & 73 & 96 \\
Hijijki & 18 & 83 & 62 & 79 \\
\hline
\end{tabular}

According to the results in (Table 5) it can be seen that Arame and Hijiki have high contents of calcium, magnesium and phosphorus. The recommended daily dose for adults up to 25 years old of calcium is $800 \mathrm{mg}$, of magnesium $350 \mathrm{mg}$ and of phosphorous $800 \mathrm{mg}$ (WHITNEY \& ROLFES, 1996). The presence of high calcium contents can represent a very good supplement in a diet which is often deficient in calcium for insufficient consumption of milk.

Table 5

Mineral composition of marine algae Arame (Eisenia bicyclis) and Hijiki (Hijikia fusiforme) in $\mathrm{mg} / 100 \mathrm{~g}$ d.w.

\begin{tabular}{|c|c|c|c|c|}
\hline \multirow[t]{2}{*}{ Minerals } & \multicolumn{2}{|c|}{ Arame } & \multicolumn{2}{|c|}{ Hijiki } \\
\hline & $\bar{x}$ & $\pm \mathrm{s}$ & $\overline{\mathrm{x}}$ & $\pm s$ \\
\hline $\mathrm{Fe}$ & 2.69 & 0.06 & 4.35 & 0.09 \\
\hline $\mathrm{Zn}$ & 1.32 & 0.04 & 0.891 & 0.021 \\
\hline $\mathrm{Ca}$ & 946 & 20 & 1156 & 29 \\
\hline $\mathrm{P}$ & 490 & 15 & 625 & 10 \\
\hline $\mathrm{Mg}$ & 410 & 12 & 634 & 19 \\
\hline I & 245 & 7 & 30 & 3 \\
\hline $\mathrm{Cu}$ & 0.989 & 0.025 & 0.946 & 0.020 \\
\hline $\mathrm{Mn}$ & 0.242 & 0.015 & 0.628 & 0.040 \\
\hline $\mathrm{Cd}$ & 0.027 & 0.006 & 0.018 & 0.005 \\
\hline $\mathrm{Ni}$ & 0.058 & 0.01 & 0.035 & 0.007 \\
\hline $\mathrm{Cr}$ & \multicolumn{2}{|c|}{$<0.005$} & \multicolumn{2}{|c|}{$<0.005$} \\
\hline $\mathrm{Pb}$ & 0.046 & 0.012 & 0.095 & 0.038 \\
\hline $\mathrm{Hg}$ & 0.025 & 0.008 & 0.027 & 0.005 \\
\hline
\end{tabular}

$\overline{\mathrm{x}}$ : Means of 3 determinations

$\pm s$ : Standard deviation of 3 determinations 
Arame and Hijiki contain 245 and $30 \mathrm{mg} / 100 \mathrm{~g}$ d.w. of iodine, respectively (Table 5). As the essential trace element iodine is an integral part of two hormones released by the thyroid gland, and its recommended daily dose for adults is $150 \mu \mathrm{g}$ $(0.150 \mathrm{mg})$ (WhitNEY \& ROLFES, 1996). The daily requirement of iodine would therefore be satisfied with $61 \mathrm{mg}$ d.w. of Arame and $500 \mathrm{mg}$ d.w. of Hijiki. The deficiency of iodine as well as its excessive accumulation in the tissue can cause serious health impairments. The toxic dose of iodine for adults is over $2000 \mu \mathrm{g} \mathrm{(2} \mathrm{mg)} \mathrm{per} \mathrm{day}$ (WhitNEY \& ROLFES, 1996), meaning that the intake of $816 \mathrm{mg}$ d.w. of Arame and $6.67 \mathrm{~g}$ of Hijiki per day would be allowed.

The same daily intake of Arame and Hijiki would supply 8 and $77 \mathrm{mg}$ of calcium, 4 and $42 \mathrm{mg}$ of phosphorous, respectively while the contribution of magnesium would be 3 and $42 \mathrm{mg}$, respectively. The allowed daily amount of Hijiki would therefore supply as much as $10 \%$ of daily dose in calcium, $5 \%$ in phosphorous and $12 \%$ in magnesium.

Three heavy metals mercury, lead and cadmium are the most toxic for the man (WhitNEY \& ROLFES, 1996). The determined quantities of mercury (Table 5) is much inferior to the tolerable weekly intake, of $0.3 \mathrm{mg}$ total mercury per person (CONCON, 1988) i.e. cca $0.04 \mathrm{mg}$ daily, established by FAO/WHO Expert Committee in 1972. Allowed daily cadmium intake in humans established by FAO/WHO Expert Committee is $50-150 \mu \mathrm{g}(0.05-0.15 \mathrm{mg})$, meaning that daily intake of $200 \mathrm{~g}$ d.w. of analysed algae hardly reaches the critical quantity of cadmium. In 1971 WHO suggested a limit for lead of $100 \mu \mathrm{g} \mathrm{l}^{-1}$ of drinking water i.e. $250 \mu \mathrm{g}$ daily, if it is assumed that 2.51 of water is consumed daily (CONCON, 1988). In Hijiki where the quantity of lead is found to be twice as high as in Arame, the daily intake of cca $300 \mathrm{~g}$ d.w. would be allowed.

\section{Conclusions}

- The proteins of analysed algae contain all essential amino acids with high values of amino acid ratios except for tryptophane, which represents the first limiting amino acid.

- The high contents of undigestible carbohydrates contribute to the total amount of dietary fibres consumed daily, representing an important factor of self-protection.

- The analysed algae, especially Arame, are the source of iodine, the quantity of which should limit algal daily intake.

- In combination with other food the analysed algae contribute to satisfy the recommended doses in calcium, magnesium and phosphorous.

- Considering the low amount of nucleic acids and heavy metals, the analysed algae consumed as food supplement can improve the nutritive value of our staple diet. 


\section{References}

A.O.A.C. (1990): Method 976. 05 (proteins), 920. 39 (Fats), 962.09E (cellulose), 900. 02 (ashes), 975. 03 (minerals), 931. 01B (phosphorus), 935.14 (iodine). Offical methods of analysis. 15th ed. pp. 72, 79, $80,1012,42,56,87$

CAHYANA, A. H., ShutO, Y. \& KinOShitA, Y. (1992): Pyropheophytin as an antioxidative substance from marine alga, Arame (Eisenia bicyclis). Biosci. Biotechnol Biochem., 56 (10), 1533-1535.

CHANG, J. Y., KNECHT, R. \& BRAUN, G. (1983): Methods in enzymology. Vol 91, Academic Press. Inc., New York, pp. 41-48.

COnCON, J. M. (1988): Food toxicology. Part A, Marcel Dekker Inc., New York, pp. 582, 1049-1073.

EDOZIEN, J. C., UDO, U. U., YOUNG, V. R. \& SCRIMSHAW, N. S. (1970): Effects of high levels of yeast feeding on uric acid metabolism of young men. Nature, 228, 180.

FAO/WHO/UNU (1985): Energy and protein requirements. Report of a joint FAO/WHO/UNU expert consultation, WHO Techn. Rep. Ser. N. 724, Geneva, Switzerland.

FLEURY, N., \& LAHAYE, M. (1991): Chemical and physico-chemical characterisation of fibres from Laminaria digitata (Kombu Breton) a physiological approach. J. Sci. Fd Agric., 55, 389-400.

FUJIWARA-ARASAKI, T. (1984): In vitro digestibility of algal proteins. Jap. J. Phycol. (Sorui), 32, $293-299$.

FUJIWARA-ARASAKI, T., MINO, N. \& KURODA, M. (1984): The protein value in human nutrition of edible marine algae in Japan. Hydrobiologia, 116/117, 513-516.

HARWOOD, J. L., PETTITT, T. P. \& JONES, A. L. (1988): Proceedings of Phytochemical Society of Europe Biochemistry of Algae and Cyanobacteria. Book News Inc., New York, pp. 49-67.

HOSONEY, R. C. (1994): Principles of cereal science and technology. American Association of Cereal Chemists, Inc, St. Paul, Minnesota, p. 77.

HuGLI, E.T. \& MOORE, S. (1972): Determination of tryptophan content of proteins by ion exchange chromatography of alcaline hydrolysates. J. Biol. Chem., 247, 2828-2834.

LAHAYE, M. (1991): Marine algae as sources of fibres: Determination of soluble and insoluble dietary fibre contents in some "sea vegetables". J. Sci. Fd Agric., 54, 587-594.

LEDVINKA, F. (1986): Macrobiotica. Pianeta Terra Ed., Firenze, pp. 24-25.

LEHNIGER, A. L. (1982): Principles in biochemistry. Worth Publishers Inc., New York, pp. 635-636, 707.

MAHASNEH, I., JAMAL, M., KASHASHNEH, M. \& ZIBDEH, M. (1995): Antibiotic activity of marine algae against multi-antibiotic resistent bacteria. Microbios., 83 (334), 23-26.

OKAI, Y., HiGASHI-OKAI, K., ISHIZAKA, S. \& YAMASHITA, U. (1997): Enhancing effect of polysaccharides from an edible brown alga Hijikia fusiforme (Hijiki), on release of tumor necrosis factor - alpha from macrophages of endotoxin - nonresponder C3H/HeJ mice. Nutr. Cancer, 27 (1), 74-79.

RUT, M. (1973): Stanovení nukleových kyselin v kvasnikách. (Determination of nucleic acids in yeats.) Kvasný Prúmysl, 19, 131-133.

SARWAR, G. \& MCCONOUGH, F. E. (1990): Evaluation of protein digestibility - corrected amino acid score method for assessing protein quality of foods. J. Assoc. off. Chem., 73 (3), 347-356.

SARWAR, G., PEACE, R., W. BOtTING, H. G. \& BRULE, D. (1989): Relationship between amino acid scores and protein quality indices based on rat growth. Plant Foods for Human Nutr., 39, 33-44.

StOCCHI, V., CUCCHIARINI, L., PiCCOLI, G. \& MAGNANI, M. (1985): Complete high-performance liquid chromatographic separation of 4-N, N-dimethylaminoazobenzene-4'-thiohydantoin and dimethylaminoazobenzene-4'-sulphonyl chloride amino acids utilizing the same reversed-phase column at room temperature. J. Chromatogr., 349, 77-82. 
StocChi, V., PiCColi, G., Magnani, M., PALma, F. Biagiarelli, B. \& CuCChiarini, L. (1989): Reversedphase high-performance liquid chromatography separation of dimethylaminoazobenzene sulfonyl and dimethylaminoazobenzene thiohydantoin-amino acid derivatives for amino acid analysis and microsequencing studies at the picomole level. Anal. Biochem., 178, 107-117.

TROWELL, H. (1976): Definition of dietary fiber and hypotheses that it is a protective factor in certain diseases. Am. J. clin. Nutr., 29, 417-427.

VOLESKY, B. \& HOLAN, Z. R. (1995): Biosorption of heavy metals. Biotechnology. Prog., 11, 235-250.

WHITNEY, E. N. \& ROLFES, S. R. (1996): Understanding nutrition. 7th ed., West Publishing Co., New York, pp. 454-455, 493-494, 708 . 